\title{
COMPROMISE TO A CORRECT RESULT: RETENTION AND MODIFICATION OF THE COMPULSORY LICENSE IN PROPOSED COPYRIGHT LAW REVISION $\dagger$
}

The compulsory license, claimed by songwriters and music publishers to be restrictive and anachronistic, apparently will continue to set the rules regulating mechanical reproduction of phonograph records in the United States. Despite the recommendation of the Register of Copyrights to eliminate the compulsory license, ${ }^{1}$ proposed legislation which will completely revise the Copyright $\mathrm{Law}^{2}$ retains the statutory licensing system. Why, despite complaints and contrary recommendations, will copyright law continue to embody a provision which allows anyone to produce his own version of existing recorded music and then market a phonograph record of the composition, paying the owner of the composition only a few cents a copy? The answer is, in part, that the sections of the proposed act dealing with the phonograph record industry seem to be a compromise between the conflicting interests of the record manufacturers and the composer-publishers. ${ }^{3}$ But regardless of how the final form of the legislation was achieved, the compromise which allows continuation of the compulsory license with proposed modifications is the best possible result for the recorded music industry as a whole.

I

\section{THE PRESENT SYSTEM}

Writers have recently questioned whether the original enactment of the compulsory license provisions in 1909 was "a wholly unjustified compromise even then." Adoption of the compulsory license was brought

$\dagger$ This paper has been awarded First Prize in the 1965 Nathan Burkan Memorial Competition at the School of Law, University of Cahfornia, Berkeley.

1 Staff of House Compa. on the Judictary, 87tre Cong., IST Sess., Report of the Register of Copyrights on the General Revision of the U.S. Copyright Law 36 (Comm. print 1961) [hereinafter cited as REPORT OF THE REGISTER].

2 In its latest form, the proposal for revision of Copyright law was introduced as identical bills in the House, H.R. 4347, 89Tr CoNG., 1ST SEss. (1965), and Senate, S.1006 89th Conc., 1st Sess. (1965) [hereinafter cited as "Proposed Act"]. Known as the McClellanCeller Bill, the proposed act's purpose is to amend Title 17 of the United States Code in its entirety. If enacted, the effective date of the legislation will be January 1, 1967.

3 Kaminstein, The McClellan-Celler Bill for General Revision of the Uniled States Copyright Law, 10 N.Y.L.F. 147, 149 (1964); Kaminstein, Copyright Symposium: Revision Viewpoints, 11 BULL. CR. Soc. 3, 4 (1963). See also Celler, Copyright-New Frontiers, 10 BUx.L. CR. Soc. 84, 87 (1963), suggesting the nature of compromises in the music copyright field.

4 Staft of House Comom. on the Judictary, 88th Cong., 1st Sess., Copyright Law Revision, Part 2: Discussion and Comments of the Report of the Register of CopyrJghts oN the Generat ReVision of the U. S. Copyright LaW 62 (Comin. print 1963) 
about by the Supreme Court's 1908 decision in White-Smith Music Publishing Co. v. Apollo Co. ${ }^{5}$ The Court held that the making and sale of a pianola roll, and by analogy of any disks of a copyrighted musical composition, did not constitute copying within the terms of the then existing statute ${ }^{6}$ and therefore White-Smith's copyright had not been infringed. Thus the copyright owner had no exclusive right to make a sound recording of his own musical work. To deal with the Apollo case, ${ }^{7}$ section 1(e) of the 1909 act $^{8}$ established the copyright owner's right to record and mechanically reproduce his musical compositions, and section 25 (e) specified remedies for the infringement of such rights. ${ }^{9}$ In the committee hearings and general revision bills leading to the act of 1909 , it was proposed that the copyright owner be given exclusive mechanical reproduction rights in the sane way similar rights are given exclusively. It was learned, however, that the Aeolian Company, anticipating the establishment of an exclusive recording right, had contracted with the leading music publishers for the exclusive right to record all their music. To placate those who feared monopolization, the compulsory license was adopted..$^{10}$

Although there have been numerous proposals to alter the compulsory license provisions, they have remained virtually unchanged since 1909: Once the copyright owner records his musical composition or permits or knowingly acqniesces in such a recording within the United States, thereafter anyone else may nuake "similar use" of the composition upon the payment of the prescribed royalties for "each such part manufactured." Upon permitting the first record to be made, the copy-

[hereinafter cited as CopYRIGHT Law Revision, PaRT 2] (comment by John Schulman); see, e.g., Joiner, Analysis, Criticism, Comparison and Suggested Corrections of the Copyright Law of the United States Relative to Mechanical Reproduction of Music, 2 CopYRIGET Syanosius 43,58 (1940).

5209 U.S. 1 (1908).

6 The Act of March 3, 1891, ch. 3, § 4952, 26 Stat. 1106, provided that the author of a copyrighted musical composition should have "the sole liberty of printing, reprinting, publishing, completing, copying, executing, finishing and vending the same."

7 While the result of the Apollo case was changed by the 1909 act, the underlying rationale remains intact. Thus recordings are still not "copies" of the musical composition or "writings" under the present copyright law.

817 U.S.C. \& 1(e)! (1964).

817 U.S.C. $\$ 101$ (e) (1964).

10 Report of the Register 32; Stafe of Sub-Comm. on Patents, Tradeararks and Copyrigets, Senate Compr. on the Judictary, 86 mi Cong., 1st Sess., Studx No. 5, Compulsory License Provisigns of the U. S. Copyright Law 1-12 (Comm. print 1960) (study by Harry G. Henn) [hereinafter cited as STUDY No. 5].

11 Records are referred to as "parts" from the phrase "parts of instruments serving to reproduce mechamically the musical work," 17 U.S.C. \& 1(e) (1964), derived from terminology of piano rolls in White-Smith Publishing Co. v. Apollo Co., 209 U.S. 1 (1908). NIMOMER, COPYRJOHT 424 n.281 (1964). 
right owner must file a notice of use, accompanied by a recording fee, in the copyright office. This procedure gives the general public notice that the work may thereafter be recorded by anyone, subject to the obligations of compulsory license. The proprietor's failure to file a notice of use is a complete defense to any action for infringement of the recording or of the mechamical reproduction rights. Any person who wishes to take advantage of the compulsory license nuust serve a notice of intention on the copyright proprietor and send the copyright office a duplicate notice. Failure to file these notices malses the unauthorized manufacturer liable for treble royalties, in the court's discretion, in addition to the other royalties payable. ${ }^{12}$

Today compulsory license seems to be most significant in the popular music field, where the large volume of sales establishes substantial fees owing to songwriters. However, due to practices and relationships in the recorded nusic industry, the effect of compulsory hicense is soniewhat speculative. A songwriter does not ordinarily directly license his music for recording; he assigns his interest to a music publisher under a standard form contract which mcludes the right to secure a statutory copyright in the publisher's name. The music publisher then arranges for the dissemination of the musical composition through various media. One of the nuusic publisher's first moves, frequently even before sheet music publication, is to attempt to have the composition recorded. In almost every instance, the publisher contracts with the record companies irrespective of the Copyright Act. Particularly in the popular music field, the song owner aims at the widest dissemination possible and rarely demands the statutory rate for subsequent recordings. ${ }^{13}$ Thus while the conpulsory license does not absolutely estabhish the return to the songwriter, it serves as a framework for contracting concerning reproduction rights.

The economic importance of hicensing mechanical reproductions can be determined because record companies report they pay six and one-half per cent of their gross revenue to songwriters and publishers for the right to record their songs. ${ }^{14}$ In 1965 songwriters and music publishers

1217 U.S.C. § 1(e) (1964). See generally NIMLMER, CopyrugHT 421-25 (1964); SrUdY No. 5, at 15-20; Evans, The Law of Copyright and the Right of Mechanical Reproduction of Musical Compositions, 3 Copyriger Law Symposium 118-31 (1941). A further analysis of the present copyright law and comparison with the proposed act appears Part III infra.

13 Staff of the Suz-Comom. on Patents, Trademarks and Copyrtgits, Senate Comms. on the JUdictary, 86th Cong., 1st. Sess., Study No. 6, Economic Aspects of the CompulSORY LICENSE 93-95 (Comm. print 1960) (study by William M. Blaisdell) [hereinafter cited as STUDY No. 6].

14 Study No. 6, at 103-04. Song writers and publishers are considered together because the publisher is actually contracting with the record company on behalf of himself and the writer, and under the standard form contract, songwriter and publisher sphit the amount received from record companies equally. 
each are expected to gross over twelve million dollars from mechanical royalties. The gross sales of the record industry in 1965 are figured to exceed 800 million dollars, ${ }^{15}$ which will net record producers about fifteen million dollars. Thus a significant part of the income of the music industry is derived from mechanical reproduction, and the songwriterpublisher's share if not derived directly front the compulsory license provisions is at least determined by the statutory system.

\section{II}

\section{THE ARGUMENTS}

Whether the compulsory license principle should be retained or eliminated is best determined by evaluating the arguments which have been presented each time attempts have been made to eliminate it. The songwriters and inusic publisliers advocate complete abolition of the compulsory license. ${ }^{16}$ The songwriters' position is supported by performing rights organizations such as American Society of Composers, Authors, and Publishers (ASCAP) ${ }^{17}$ and Broadcast Music, Incorporated (BMI), ${ }^{18}$ and was favored initially by the Register of Copyrights. ${ }^{19}$ On the other side, the record manufacturing companies, some fifty or more of whom are organized in a trade association known as the Record Industry Asso-

15 Note, Compulsory Licensing: A Controversial Topic in the Latest Revision of Our Copyright Law, 33 U. Civc. L. REv. 88 n.33 (1964). With the gross sales figure estimated at $\$ 800$ million for 1965 , the percentages of STUDY No. 6 were used to update the amount songwriters expected to gross. The figures in millions of dollars are:

\begin{tabular}{lcc}
\hline & $\begin{array}{c}1956 \\
\text { (STUDY No. 6) }\end{array}$ & $\begin{array}{c}1965 \\
\text { (Updated) }\end{array}$ \\
\hline $\begin{array}{l}\text { 1. Record business gross sales } \\
\text { 2. Revenue to record producers } \\
\quad \text { (divide gross by 2.1) }\end{array}$ & 325 & 800 \\
3. Average net profit of record \\
$\begin{array}{l}\text { producers (4\% of gross, item 2) } \\
\text { 4. Mechamical royalties } \\
\quad(6.5 \% \text { of gross, item 2) }\end{array}$ & 150 & 380 \\
5. Allocation (I/2 to songwriters, \\
$\begin{array}{l}\text { I/2 to publisher) } \\
\text { 6. Songwriters gross income } \\
\quad(21 / 2 \% \text { deduction from item 5 } \\
\text { for collection expenses) }\end{array}$ & 6 & 15 \\
\hline
\end{tabular}

16 Stafe of House Conam. on the Judictary, 88th Cong., 2d Sess., Copyright Law Reviston, Part 4: Further Discussion and Comments on Prelimmnary Draft for RevISED U.S. COPYRIGIT LAW 62 (Comm. print 1964) [hereinafter cited as Copyriget LAW Revision, ParT 4].

$17 \mathrm{Id}$. at 35 .

18 Id. at 23.

19 REPORT OF REGISTER 36. 
ciation of America, favor retention of some form of compulsory license. ${ }^{20}$ The arguments are presented in four groups: (1) the possibility of monopoly in the recorded music industry; (2) the fear of disruption of the industry if compulsory license is eliminated; (3) whether songwriters could maximize income if they had complete freedom to contract; and (4) the propriety of compulsory restrictions under the Constitution.

\section{A. Monopoly Practices in the Recorded Music Industry}

The traditional argument, which was responsible for the original establishment of the compulsory license, is that without it monopohstic conditions will develop within the music industry. There is no dispute that the competitive situation has changed since 1909. Presently there is a constantly changing roster of approximately 1,000 music recording companies in the United States. However, the seven well-established leaders account for over eighty-five per cent of the dollar volume of business, twenty-five others for an additional ten per cent, with five per cent distributed among the remaining producers. ${ }^{21}$ Such a concentration of production may mean a strong monopolistic tendency in the industry, but since all of the companies have competitors of their own size, the situation is far from the complete domination threatened by the Aeohan Company in 1909. In 1956 and 1957 the Department of Justice imvestigated the record industry concerning possible monopoly in relation to the pricing of records, but no prosecutions followed. ${ }^{22}$ The music available for recording is widely scattered among thousands of competitive publishers; some of them are large, but the great majority are small. The volume of music available for recording is immense and constantly growing.

Since monopoly practices have not existed under the compulsory license system, the record manufacturers claim it is illogical to beheve monopolies will not appear once the system is repealed. ${ }^{23}$ The Register's Report asserts that compulsory licensing is no longer justified as an antimonopoly measure, ${ }^{24}$ but the basis for the statement is only that there are now hundreds of competing record companies and hundreds of com-

20 Copyrigert LaW Revision, Part 4, at 413.

21 Based on 1965 estimated gross sales of $\$ 800$ million, see note 15 supra, the four "major producers," Capitol, Columbia, Decca, and RCA Victor, have gross sales approximating $\$ 100$ million each. The next three companies, MGM, Mercury, and London, will probably gross slightly less than the major producers, but far ahead of the rest. STudx No. 5, at 46 .

22 Study No. 6, at 109 n.48.

23 Copyriget LAw Revision, ParT 4, at 432 (statement by Record Indus. Ass'n of America).

24 REPORT OF THE REGISTER 33. 
peting music publishers. Some record compamies with no direct source of supply of musical compositions attribute their existence to the compulsory license and maintain that if it were abandoned, they would immediately be smothered..$^{25}$ These snialler companies depend on recording already popular hits with the hope their versions will get a segment of the market.

The small record companies would suffer a loss of revenue if they were precluded from recording established favorites, but at the same time they could get exclusive rights on a few of their own original records whicl might turn out to be "hits." It is a double-edged sword. Under the compulsory hicense, if a small company does bring out new music which shows promise, the larger compamies can immediately bring out the same music with larger orchestration or a more famous vocalist. The reaction of some people in the industry is that several substantial "hit" records would go as far toward substantiating the small manufacturer's position in the market as present secondary recording of established "hits," and at the same time would encourage conpetitive effort. ${ }^{27}$ However, predicting "hit" records is impossible and it is unlikely that small record companies would find it worthwhile to get exclusive rights on any songs. Further, in the popular field, the owner of the song would probably not want to sell the exclusive rights to a small conipany and rely solely on its treatment and distribution. In sum, it would not be an even exchange for the sinall record company to give up the chance of recording songs already on the way up the popularity charts in the liope of having exclusive recording rights on a song which may turn out to be a hit.

Withdrawal of the compulsory hicense could also lead to monopolization and concentration in the larger members of the industry by sealing the publishers off from the snraller companies altogether. The superior economic strength of some of the more powerful record companies would make it most difficult for the average music pubhisher to refuse any demand made upon him for an exclusive hicense. ${ }^{28}$ Besides, the lesser known manufacturers could not meet the big concern's promises of advertising

25 Staff of House CoNar. on tre Judictary, 87th Cong., 1st Sess., Copyright Law Revision, Part 3: Pretmituary Draft for Revised U.S. Copyright Law and Discussion and Comarents on the Drafi 220 (Comm. print 1964); [hereinafter cited as Copyright LAw Revision, PART 3] (statement by Morton Miller, representing Kapp Records); CopyRTGHT LAw REvision, PART 2, at 309-10 (statement by Herbert Kanon, representing Audio Fidelity, Inc.).

26 See Comment, Battle Over Compulsory License: Mechanical Recording of Music, 36 U. CoLo. L. REv. 501, 512 (1964).

27 STUdy No. 5, at 68 (comment by George E. Frost).

28 See Copyright Law Revision, ParT 4, at 437 (statement hy RIAA representative); Study No. 6, at 121 (comment by Ernest S. Meyers). 
promotions and "name" artists. The big recording company could guarantee this promotion in exchange for an exclusive license.

Although in a position to limit utilization of their song in the absence of compulsory license, it seems more probable that the composers and music publishers would use their position to maximize profits with respect to the recording of each composition by giving nonexclusive licenses to as many manufacturers as possible. Though it is conceivable that a record company might make worthwhile offers for exclusive licenses for music it beheved was the "cream," the popularity of a particular composition is highly unpredictable. The profitability of paying high rates for exclusive hicenses is doubtful and no record company could purchase all such exclusive rights. ${ }^{29}$ If owners are transferring exclusive rights to one recording company, there would be no danger of monopoly unless that company got exclusive licenses on all the music in vogue at the time, ${ }^{30}$ which is improbable. It is also possible that recording companies would purchase exclusive rights to large blocks of properties -for example, all of one composer's catalogue-paying at a bulk rate. But the negotiating strengths of the parties would still be sucl that the copyright proprietors would not give up their interests without demanding a quid pro quo which the record producers might not be willing to give. ${ }^{31}$ The owners of copyrighted songs would not want to see the development of a monopoly situation, because the strength of their bargaining position in the absence of compulsory license would depend on active bidding for the songs among the record manufacturers.

A possible alternative to exclusive licenses, wlich would result in the concentration of the industry in a few large manufacturers, is the vertical integration of the record industry. Many of the larger publishing companies are owned or controlled by major record companies, and those publishing companies would in effect give their parent companies a monopoly on licenses of many of the songs considered standards, as well as other promising tunes. ${ }^{32}$ While there is a tendency toward integration in the record industry, the contending parties-publishers and record companies-currently subject to compulsory license, are of comparatively equal stature. In the absence of a compulsory license, the relatively equal strength of the two groups would tend to assure a fair basis for bargaining, while the numbers of strong companies on each

29 STUDY No. 6, at 108.

30 Mak, Rights Affecting the Manufacture and Use of Gramophone Records 90 (1952).

31 STUdx No. 6, at 108.

32 Copyright LAW Revision, Part 2, at 262 (statement by William D. Beasley, songwriter); see Pasarow, Copyright Law Symposium: Revision Viewpoints, 11 BuLl. CR. Soc. 25 (1963). 
side would tend to maintain competitive conditions within each group. In sum, it would not be easy for the phonograph record industry to control the music publishing business and the converse would be just as difficult. ${ }^{33}$

The record companies claim that Congress in 1909 acted to permanently bar monopoly conditions froin the record industry, not just to prevent the Aeolian Company fronl obtaimng a monopoly in piano rolls at the time. The compulsory license clause bears out this theory since it was written to include phonorecords within the scope of "disks, rolls, bands or cylinders for use in mechamical music-producing machines." ${ }^{234}$ Thus, to eliminate compulsory license might be to abandon the means Congress used to insure monopoly conditions would not occur in the future in the record industry.

\section{B. Chaos and Disorder in the Recorded Music Industry}

In determining whether to abandon compulsory license, an important consideration is the effect of its elimination on the record industry. The record manufacturers fear that not only would the music industry be driven in the direction of concentration and restrictive practices, but also that there would be a general upheaval in industry structure and operation. ${ }^{35}$ The Register of Copyrights recognizes that "present practices in the record industry are based on the compulsory license, and that its ehmination would require some major adjustments and new contractual relationships. ${ }^{1386}$ In the preliminary draft of the new act, Alternative A to section 11 (compulsory license) sets out provisions for pliasing out the compulsory license after a five-year transitional period. ${ }^{37}$ Any alternative depending on a gradual bargaining away of coinpulsory license between music publishers and record manufacturers is unrealistic. First, there are so many different record manufacturers and music publishers no specific guidelines could ever be agreed on by the industry as a whole to replace the compulsory license, and second, such procedure would probably bring investigation under the Sherman Antitrust Act. ${ }^{38}$

33 STUDy No. 6, at 108-09.

34 Copyright Law Revistow, Part 4, at 432 (RIAA statement).

35 "There is absolutely no point in forcing record inanufacturers and copyright proprietors into a situation where they will have to hive with the expensive judicial processes of anti-trust decree enforcement in order to provide licenses on nondiscriminatory terms (as under the current ASCAP consent decree for performing rights), when the existing statute already accomplishes the same goal and serves the public interest by a much simpler and more expeditious method-a method with whose operation the affected industries are thoroughly familiar." Id. at $43 \%$.

36 REPORT OF THE REGISTER 35.

37 Copyruget Law Revision, Part 3, at 8.

38 Copyright Law Revision, Part 4, at 435 (RIAA statement). 
The music publishers and groups seeking elimination of the compulsory license argue it would not cause chaos to abandon licensing statutes because, as a matter of practice, compulsory license is never used in the imdustry today. If mechanical reproduction rights are not exercised by the copyriglit proprietor, anyone interested in recording the work must negotiate a license to make that use. The first company to record is usually charged a lower royalty rate than that set out in section $1(\mathrm{e})$, as an inducement since it is unknown whether the record will sell. The holder of the copyright, usually the music publisher, will sometines forego the statutory fee entirely in order to get the public exposure which a recording by a "big name" artist on a well-known label will give. If the composition proves a success, only by attracting other recording companies will the song writer receive ample mechanical royalties..$^{39}$

Since both the inusic publisher and the record manufacturer know the publisher cannot prevent subsequent recordings because of the compulsory hicense, the record manufacturer ordinarily goes ahead with the release of his recording ouce there is a record of the song already out, and later requests a license, which the publisher generally issues as a matter of routine. ${ }^{40} \mathrm{~A}$ representative of the Harry Fox Office, which issues licenses for inechanical reproduction for over 800 of the United States publishers, claims that over the years no legitimate record company has ever served notice under the compulsory hicense provision of the Act. In every instance the record company obtams an agreement with the publisher because of certain benefits derived irrespective of the Act. The coinpulsory hicense is used only by record companies with whom publishers refuse to enter into agreement. According to the Fox representative, these record companies are "irresponsible outfits-record pirates, who have manufactured and disseminated records and have not rendered statements or nıade royalty payments, either under sucl an agreement or otherwise."

In rebuttal, the record nianufacturer first replies that if elimination of the compulsory license will inake no substantial change in practical operations, there is no justification for abandoning it. ${ }^{42}$ The second reply is that the clain of minimal use of the compulsory licensing provisions is misleading because the reason the Act is not relied on is that as publisher's representative the Harry Fox Office issues a form contract

39 Study No. 5, at 49; Study No. 6, at 101; Copyrught Law Revision, Part 2, at 56 (statement by George D. Cary of the Copyright Office).

40 Diamond, Copyright Problems of the Phonograph Industry, 8 BuLl. CR. Soc. 337, 340 (1961).

41 Copyright Law Revision, Part 3, at 216-17 (statement by Julian T. Abeles).

42 Copyright Law Revision, Part 4, at 433 (RIAA statement). 
which obviates filing the statutory notice. The contract in effect says "you have advised us that you wish to record our musical composition under section 1(e) of the Act, and by signing this letter you need not file the notice." This format is used so that if the record manufacturer does not pay the royalties due, the letter can be revoked and the Fox Office can proceed under section $1(\mathrm{e})$. Since ninety-eight per cent of all hicenses issued on Fox or other forms are based on section 1(e), there must be some value derived from the compulsory license. ${ }^{43}$

\section{Maximizing Incomes of Song Writers and Publishers}

The music publishers complain that the main effect of the compulsory hicense is to set a statutory ceiling on royalty negotiation. While rights are usually initially sold to recording companies at less than the statutory rate of "two cents on each part manufactured," no recording company will negotiate to set the price higher than that amount. The imposed ceiling on bargaining for reproduction rights is the real objection of the composer-publisher group. The recording companies know all they have to do is wait until another company records the song; then they can come out with their version immediately, and pay the copyright owner no more than two cents per part (song). The Register of Copyrights predicts that the only effect of eliminating the compulsory license will be to remove the two cents ceiling because "multiple recordings would still be hicensed non-exclusively." ${ }^{\prime 44}$ The record manufacturers contend that undesirable recording companies, and distorted recordings as well as low royalty rates can be dealt with by means other than eliminating compulsory licensing completely. ${ }^{45}$

The record industry maintains that release of different versions or new arrangements of already recorded songs is healthy competition and benefits the public and composer, as well as the manufacturer. When different versions of a song are released, leaving aside the shaping of public taste by disc jockeys, the consumer is given the opportunity to choose the rendition he likes. By making this choice, the public dictates the economic success of each recording of the composition. ${ }^{46}$ Since the songwriters and publishers receive a royalty for each record sold, re-

43 Copyright Law Revision, Part 3, at 235-36 (statement by Harold Orenstein).

44 Report of the Regtster 34.

45 Copyright Law Revision, Part 4, at 430-31 (RIAA statement).

46 Copyright Law Revision, Part 2, at 69 (statement by Clive J. Davis, Columbia Records). By way of examples of the multiple recordings of some compositions, "Moon River," the Academy Award song in 1961, was available in 100 different recorded versions in 1963; Ravel's Bolero in 30 different recordings, Comment, 36 U. CoLo. L. REV. 501, 515 (1964), and the "top ten" popular songs average 6 variations on 5 different labels, STUDY No. 5 , at 78 (Comment submitted to the Copyright Office in regard to Study No. 5 by Ernest $S$. Meyers). 
turns from multiple recordings have been lucrative. New versions by new record compamies give songwriters and pubhshers ever-increasing returns for the successful publication of a song, and many more chances to reach and penetrate the market.

Some music publishers reply that the increase is not a good thing because it shortens the life of the song and limits royalty returns in the long run. ${ }^{47}$ Record compamies dispute this contention, arguing that the compulsory hicense makes it possible for a recorded song which had no initial success to be a big success when revived in another version. A song is not frozen in its initial rendition, which may have proven unpopular. ${ }^{48}$ Moreover, many times songs in the category the industry calls "standards" are rerecorded every year..$^{49}$ As a practical matter, composerpublishers attempt to have their works recorded and distributed by as many companies as possible.

It has been suggested the purpose of the copyriglit statute is to grant the author the exclusive right to publish music and have it performed in order to encourage the composition of more songs. ${ }^{50}$ If the copyright owner did choose to grant exclusive hicenses, the companies would not compete with various recordings of the same inusic, but with recordings of different music. The result might be a larger number of compositions by a larger number of songwriters offered to the public on records issued by the various companies. ${ }^{51}$ An increased number of really different compositions seems an unreahstic expectation since composers, especially in the popular field, would continue to produce tunes with the same rhythm and sound as other currently popular songs, rather than creating a greater number of different compositions.

As to increased royalties, composer-publishers feel that maximization can come only when they have complete freedom to contract and the ability to license or not to license a recording company. Publishers also contend that there can be no real incentive to produce music unless authors and composers have an opportunity to seek what they consider reasonable compensation for their work, and "the indiscriminate reproduction of a copyright owner's work without his consent violates the underlying concept of copyright protection." What Whether abandoning the

47 Copyrtght Law Reviston, Part 2, at 64 (statement by Philip B. Wattenberg on behalf of music publishers).

48 Coprricht Law Revision, Part 2, at 71 (statement by Sydney M. Kaye, Broadcast Music, Inc.).

40 Copyriger Law Revision, Part 4, at 434 (RIAA statement). For example, "White Christmas," "Stardust," and "Oklahoma."

50 Joiner, supra note 4 , at $5 \%$.

51 See REPORT OF THE Register 34; StudX No. 6, at 110; Finkelstein, The Inequitable Compulsory License Provision, 10 N.Y.L.F. 168-69 (1964).

52 Copyricht Law Revision, Part 2, at 228 (Statement by American Book Publishers Institute). Sec also Finkelstein, supra note 51, at 170 . 
ceiling on royalties compelled by the compulsory license would in fact increase songwriters' income is theoretical. It might turn out that in a free bargaining situation, the song publisher could secure no more royalties than the statute presently guarantees. In any case, the plea for freedom to contract without restrictions seems to be merely a spurious argument designed to secure the raising of the ceiling imposed by the statutory recording rate.

\section{Compulsory License and the Constitution (Herein Analogy to Performers' Rights)}

The United States Constitution, article I, section 8, empowers Congress "to promote Progress of Science and the Useful Arts by securing for limited tines to Authors and Inventors, the exclusive right to their respective Writings and Discoveries." Copyright proprietors have traditionally argued that because the statutory provisions place the composer in a position where he cannot collect the benefits of his composition except by giving others the right to do likewise, it can hardly be said that his rights are exclusive; thus, they argue, the compulsory license infringes the exclusive right granted in the Constitution. ${ }^{53}$ Songwriters liave, however, hesitated to challenge the compulsory hicense as unconstitutional for fear the entire section of the Act would be invalidated, leaving them with no protection against unauthorized recordings. ${ }^{54}$

The constitutional argument is generally recognized as invalid. ${ }^{55}$ In the first place, Congress has discretion to enact copyright legislation or not-to grant exclusive rights or no protection at all. The protection of the compulsory hicense is somewhere between these polar positions-a reasonable middle ground. The tern "exclusive right" imphes authority but not hinntation. Second, Congress did grant the exclusive right to the musical copyright owner, but provided that once the right is exercised, directly or by means of a license, the right is no longer exclusive. Third, the compulsory license principle was not incorporated in the statute to impair an existing right, but was inserted as part of the defimition of rights being recognized for the first time. ${ }^{.6}$

Provisions similar to the compulsory hicense appear elsewhere in the Copyright Act: Proprietors of nusical and nondramatic literary copyriglits do not have the exclusive right to perforn their works publicly-

03 See Note, 33 U. Cinc. L. Rev. 95-96 (1964); Comment, 36 U. Coro. L. Rev. 501, 513 (1964).

64 STUDY No. 5, at 23 (testimony of Nathan Burkan).

55 See NIMaIER, Coprright 14 (1964).

56 CopYright LAw Revision, Part 4, at 429 (RIAA statement); NIMaMer, Coryriget 14 (1964). 
they have only the right to perform their work publicly for profit. ${ }^{57}$ There is a close analogy between access to performing rights and access to recording rights, simce both serve similar practical needs in the music industry. In the field of live or broadcast performances the artist must have immediate access to copyrighted musical compositions on nondiscriminatory terms without substantial risk of liability for copyright infringement. Likewise, phonograpli record manufacturers need access to musical compositions so the artist can go before the recording microphone and record anything in his repertoire without hindrance.

Copyright proprietors faced with the practical problem of enforcing their rights agaimst a multitude of users of music in public performances naturally tended to join forces to form performing rights societies to police this use. The best known groups of this type are American Society of Composers, Authors and Publishers (ASCAP), and Broadcast Music, Inc. (BMI). Today, the performing rights society typically grants blanket licenses covering the rights to perform publicly for profit all the copyrighted inusic that it controls, in exchange for an appropriate percentage of the licensee's gross income. Due to the concentration of power which developed in ASCAP, a civil antitrust action was instituted whicl resulted in a series of consent decrees beginning in 1941. The current decree (including 1960 amendments) contains provisions which operate just like compulsory license. Any user who requires a performing rights license is entitled to receive one from ASCAP or BMI on nondiscriminatory terms. If an agreement cannot be reached on rates by negotiation, the user may apply to the United States District Court for the fixing of a reasonable rate. ${ }^{58}$ The result: Artists performing copyrighted musical compositions in public for profit and artists seeking to record such compositions are in exactly the same position-they are free to perform or record any number in their repertoires.

It is almost unthinkable that an artist could be prevented from smging or playing all the musical compositions in his repertoire on stage, in a cabaret, or in a radio or television studio. Were the compulsory license provision of the copyright act eliminated, however, the recording studio would be set apart from the public appearance, and the artist would no longer be free to record whatever he chose. ${ }^{69}$ As one record company representative put it:

Why should there be any inhibition on a great artist . . . who has in his live concert repertoire a work which is still in copyright, when the recording company to which he is under contract wants to issue a

ธ7 17 U.S.C. $\&$ I(e) (1964).

58 CopYRIGHT LAW RxVISIon, PART 4, at 440-44 (RIAA statement).

59 Id. at 444. 
record of that performance, why should there be any question about the possibility of having that performance recorded? ${ }^{60}$

A record manufacturer may presently plan album releases knowing he can obtain, at a set price, any song he needs which has already been recorded. If compulsory license were eliminated, a music publisher owning a number of one writer's works could refuse to grant a hicense except at an unusually high rate or as part of a package deal with other unwanted songs, thus thwarting the planned album. ${ }^{61}$ Further, if the copyrighted material happened to be an important part of a recording artist's live repertoire, by withholding the right to record, the song owner could undermine the artist's popularity. ${ }^{62}$

It is possible to draw distinctions between recording rights, which produce a copy of the song which can be replayed at will, and a fleeting public appearance by the artist, but the distinction may not have enough significance to warrant ehimination of the compulsory license. Since the Constitution does not compel abolition of the compulsory license, the analogy to performers' rights argues persuasively that there is a substantial economic and social justification for continuing to follow the principle of full accessibility of a copyrighted musical composition to anyone for recording purposes. ${ }^{63}$

\section{E. The Arguments Weighed}

The arguments and counter-arguments of the record manufacturers and publishlier groups seem evenly balanced; it would be unrealistic to choose between the polar positions of retaining the compulsory license exactly as it is or eliminating it entirely. From an analysis of the record manufacturers' argnments, they seem most concerned, first, about retaining the guaranteed right of free access to all copyrighted musical works, and second, about preserving the stability and order of the industry while avoiding antitrust investigations. These goals are irreconcilable with elimination of the compulsory license system. The composerpublisher representatives are primarily interested in three areas: improving their position as to royalties from recorded music, both by increas-

60 Copyright Law Revision, Part 2, at 65 (statement by Sidney A. Diamond, London Records).

61 Srudy No. 6, at 122 (comment by Ernest S. Meyers).

62 Copyrighi Law Revision, Part 4, at 437, 444 n.76 (RIAA statement). Such "tied" sales of wanted and unwanted compositions, and refusals to deal, would raise serious questions under the antitrust laws. On refusal to deal, see, e.g., Klor's Inc. v. Broadway-Hale Stores, Inc., 359 U.S. 209 (1959). On tied sales, see, e.g., Northern Pac. Ry. v. Umited States, 356 U.S. 1 (1957); Times-Picayune Pub. Co. v. United States, 345 U.S. 594 (1953); International Salt Co. v. United States, 332 U.S. 392 (1947).

63 See STUdy No. 5, at 67 (comment by Edward A. Sargoy raising the issue of social or economic justification for continuing the compulsory license). 
ing the amount and clamping down on companies who refuse to pay for recording rights; broademing their freedom to contract and clarifying the areas in which compulsory license does not operate; and controlling the quality of recordings which are produced from their original compositions. Increasing royalties seems to be the real consideration, while freedom of contract and control of the quality of recordings are to some extent sham arguments to buttress the composer-publishers' position. In any case, all these goals can be achieved within the framework of a modified compulsory hicense system.

III

THE PROPOSED ACT

The proposed act, while retaining the statutory licensing system, modifies and clarifies practice in the music industry. In almost every instance, the modifications favor the composer-publisher interests. In some cases, the modifications may be considered concessions by the record manufacturers. However, they are generally concessions which reputable record companies are not unwilling to make, especially in preference to the disruption of the industry which the record manufacturers anticipate if the compulsory license were abandoned. The modifcations in the conipulsory license system made by the proposed act can be divided into four areas: (1) amount of royalties, (2) sanctions for failure to give notice of use or failure to pay royalties, (3) sanctions for distorted use, and (4) scope of the compulsory license.

\section{A. Royalties}

The royalty estabhshed in 1909 was "two cents on each part manufactured," ${ }^{\prime 64}$ two cents being the then approxiniate equivalent of five per cent of the manufacturer's selling price. The two cents is generally payable for each conposition appearing on a single record. ${ }^{65}$ Today two cents returns no more than two to two and one-half per cent based on the current price of eighty-nine cents to one dollar for popular 45 r.p.m. recordings.

A royalty fixed by statute may be stated in amount (as in the present section $1(\mathrm{e})$ ), or percentage (based on manufacturer's price or retail price), or a combination thereof (higher or lower of amount or percentage), or the rate fixed in the original negotiated license whicl activates the compulsory license provision.$^{66}$ Composer-publishers reacted unfavorably to proposals for a royalty based on a so-called "retail hist price" 
or. "suggested retail price." the lists do not always reflect the true selling price, the copyriglit owner could not police or keep track of the royalty earnings. To determine the royalty rate by the amount set in the original negotiated license is unsatisfactory because it would require computing the amount under the varying provisions of each original hicense and supplying an alternative rate if the copyright owner made his own recordings. Royalties set at a fixed amount are preferable; they are simple to compute, even when there is a differentation between records of varying lengths. ${ }^{68}$ The present practice pays for LP (long playing) and EP (extended play) records at the rate of one cent for each four minutes with one-fourth cent for each additional minute or fraction thereof, with the minimum set at two cents. ${ }^{69}$

The proposed Act in effect embodies the trade practice and increases the royalty payable under compulsory license: "With respect to eacl work embodied in the phono-record, the royalty shall be either three cents, or one cent per minute of playing time or fraction thereof, whichever amount is larger."

The royalty can be based on records "manufactured" in the United States, which is the present statutory inethod under section 1(e), or on records "sold" here, which is the present negotiated method, ${ }^{71}$ or on every record "distributed" in the Uinited States. ${ }^{2}$ To change the statutory terminology from "manufactured" to "sold" or "distributed" is more complex than it might seem. Record companies usually have about ten per cent of their records returned to them as no longer saleable, especially in the popular inarket where a record niay be a fast seller for only two weeks. If royalty payments are required on records "manufactured," the manufacturer must pay even thougli lie lias not actually received paynent for the record; thus, the inanufacturer bears the loss of bad debts. Normally, returns to the manufacturer are allowed to be nade within a six-month period, so it would be unreasonable to require the manufacturer to pay all royalties until the six-month period had elapsed if payment was based on "distribution" or "net sales."73

Another practice in the record industry calls for giving free records, which would escape royalty paynnent if the act was changed to a basis of

67 Coptright Law Revision, Part 4, at 317 (statement by Authors League of America). 68 STUd No. 5 , at 55 .

69 STUDY No. 5, at 70-71 (comment by Sydney M. Kaye), 79 (comment by Ernest S. Meyers).

70 Proposed Act $\S 113(c)(2)$.

71 STUdy No. 5 , at 55 .

72 Copyright Law Revision, Part 3, at 9 (Alternative B, Proposed Draft of $\S 1$ 1 (b)).

73 CopXright LAw Reviston, PART 3, at 435 (comment by George Schiffer). 
"sales." Several thousand copies are given to radio stations, disc jockeys and as other promotional material. Distributors receive extra copies of popular singles and also get "deal" records as part of large orders, to induce the sale of the "deal" records rather than other items. ${ }^{74}$ There are also record clubs, whereby free records are offered to the public as an inducement to contract to purchase other records.

Music industry practice, when a license is negotiated, is to make payments for all records sold and paid for, that is, the net after free records and bad debts. In the audit there is a discount allowed for free albums given in promotion deals. ${ }^{75}$ There is no reason for the statute to take notice of the trade practice in this area since the parties can adjust the terms by contract. Thus by continuing the terminology of the present statute providing "the royalty under a compulsory license shall be payable for every phonorecord made in accordance with the license," act preserves the result most favorable to the copyright proprietor. The burden is thus on the manufacturer to pay royalties for every record "made" unless he contracts otherwise.

\section{B. Failure to Pay Royalties and Failure to File Notice of Use}

Collection of royalties for mechanical reproduction of a musical work under the present statute can be divided into two categories: collection from authorized users who fail to pay royalties and collection from infringing unauthorized users who fail to report their use at all. Any person who wishes to take advantage of the compulsory license must serve notice by registered mail on the copyright proprietor of his intention to record a composition under such license and send the copyriglnt office a duplicate notice. ${ }^{77}$ The notice of use is phrased in terms of "intends to use," the prospective language suggesting notice must be served before records are manufactured; ${ }^{78}$ the trade practice is, however, contrary, as records are usually manufactured and distributed and then a license is obtained as a matter of course. ${ }^{79}$ The courts liave granted some leeway in the filing of notice, in one case allowing notification after close of the infringement trial, but before appeal. ${ }^{80}$ The result is that there is some merging of authorized and unauthorized use under the present statute.

The proposed act clarifies notice of intention to obtain compulsory license-"any person wlo wishes to obtain a compulsory license shall,

74 Ibid.

75 Ibid.

78 Proposed Act \& $113(c)(2)$. (Emphasis added.)

7717 U.S.C. $\S 101$ (e) (1964).

78 NIMOMER, COPYRIGET 423 (1964).

79 STUdY No. 5 , at 56.

80 G. Ricordi \& Co. v. Columbia Graphophone Co., 263 Fed. 354 (2d Cir. 1920). 
before or within thirty days after making, and before distributing any phonorecords of the work, serve notice of his intention to do so on the copyright owner." royalties are payable on records "made," the manufacturer will be liable even if he never distributes. Thus he has thirty days to file notice even if he decides not to distribute or be hable as an infringer. As a practical matter, under compulsory hicense, the copyright owner cares only about actual distribution and sale because they usually occur simultaneously with manufacture. If the recording company does not distribute, it usually means either the company is insolvent or is certain the record will not sell, in. which instance they will have pressed only a few copies-in either case, the copyright owner will not care about pursuing the company for royalties.

Under the present act, the manufacturer of the records is specifically designated as the party who is to pay the royalty for authorized use. ${ }^{82}$ To be considered a "manufacturer" one needs only to perform a substantial number of the steps in the manufacturing process. ${ }^{83}$ Subcontractors, shareholders, officers and directors are probably not liable under a reading of "manufacturing" which requires the doing of essential steps to produce a record. ${ }^{84}$ In the proposed act there is no specific statement as to who shall pay the royalty. The section on filing notice of intent to use, refers to "any person wishing to obtain compulsory license," section on failure to receive royalties, requires the copyright owner to give notice to the "licensee." 88 It may be inferred that the failure to continue the specific reference to "manufacturer," and the broad terms which are used, serve to expand the number of persons who will be responsible for paying royalties under an authorized compulsory license.

To be eligible to receive royalties under the present compulsory hicense system, the copyright owner must, upon permitting the first record to be inade, file a notice of use, accompanied by a recording fee, in the copyright office. ${ }^{87}$ This procedure gives the general public notice that the work may thereafter be recorded by anyone, subject to the obligation of the statutory royalties. Failure to file the notice is a complete defense to any suit claiming royalties for, or infringement of, the copyright. The notice may be filed at any time; no lability will attach to the manufacture occurring prior to filing. Once the notice is filed, any

81 Proposed Act $\S 113(\mathrm{~b})(1)$.

8217 U.S.C. \& 1(e) (1964).

83 NMMMER, COPYRIGET 426 (1964).

84 Cf. Reeve Music Co. v. Crest Records, Inc., 285 F.2d 546 (2d Cir. 1960).

85 Proposed Act $\S 113(6)(1)$. (Emphasis added.)

86 Proposed Act \& $113(\mathrm{c})(4)$.

8717 U.S.C. \& 1(e) (1964). 
unauthorized manufacture of records which occurs thereafter will not be immunized from liability by reason of belated filing. ${ }^{88}$ The proposed act explicitly continues this rule. ${ }^{89}$

Under the present statute, a subsequent recorder can bring the compulsory hicense into play "whenever the owner of a musical copyright has used or permitted or knowingly acquiesced in the use of the copyriglited work upon the parts of instruments serving to reproduce mechamically the inusical work." more control of the time his composition will be released. The owner must authorize distribution to the public, not merely acquiesce to another's use. ${ }^{91}$

The present copyright statute provides that the owner may require a report as to the number of records manufactured in the preceding month, and royalties shall be due upon the twentieth of the succeeding month. ${ }^{92}$ If the manufacturer keeps inadequate books, any doubts will be resolved in the owner's favor:. ${ }^{93}$ There is no other penalty set out in the act for failure to comply with the bookkeeping requirements. The proposed act adopts industry practice and requires only quarterly payments, which upon the copyright owner's demand must be accompanied by a detailed statement of account certified by a public accountant. ${ }^{94}$ Further, "if the copyriglit owner does not receive the quarterly payment and statement of account when due, he may give written notice to the licensee that unless the default is remedied within thirty days from the date of notice, the compulsory license will be automatically terminated." A termination renders the subsequent making of phonograph records fully actionable infringements. The new proposals would force the record manufacturers to meet royalty payments or lose the recording right of a particular composition altogether, and face an action for infringement. Catching up with companies who neglect to pay royalties even after filing notice of use is one of the big concerns of composer-publisher interests,

88 NTMAMER, COPYRTGET 422-23 (1964).

89 "To be entitled to receive royalties under a compulsory license, the copyriglt owner must be identified in the registration or other public records of the copyright office. The owner is entitled to royalties for phonorecords made after le is so identified but he is not entitled to recover for any records previously made." Proposed Act \& 113(c)(1).

9017 U.S.C. $\S 1(\mathrm{e})$ (1964).

91 "When phonorecords of a nondramatic musical work have been distributed to the puhlic under the authority of the copyright owner, any other person may . . o obtain compulsory license to make and distribute phonorecords of the work." Proposed Act $\S 113(\mathrm{a})(1)$.

9217 U.S.C. \& 1 (e) (1964).

93 NTMARER; COPYRIGHT 424 (1964), citing Shapiro, Bernstein \& Co. v. Remington Records, Inc., 265 F.2d 263 (2d Cir. 1959).

94 Proposed Act \& $113(c)$ (2).

95 Proposed Act $\S 113(c)(4)$. 
because under the present statutes, recording companies do not always pay. ${ }^{96}$

The major concern of composer-pubhisher interests in regard to the compulsory hicense seenus to be record companies which use the copyrighted music without notifying the copyright owner, and thus without authorization. Even with reputable recording companies it is often necessary under the present law to discover they have recorded the music and to serve notice before the copyright owner can collect. ${ }^{97}$ In the case of fly-by-night record companies, nuost publishers are simply unable to cope with the problem of locating the licensees and collecting royalties from these nuarginal and often unscrupulous operators. ${ }^{98}$ Attorneys dealing with these cases indicate that the recovery from small inanufacturers even after a successful court prosecution approximates 500 dollars. The small recovery occurs due to damage provisions of the current copyright law which preclude a normal measure of recovery ${ }^{99}$ and direct the plaintiff to recover back royalties of two cents per unauthorized record as provided in section 1(e), plus up to three times that amount as penalty, plus costs and counsel fees. The ceiling is thus set at eight cents per record, ${ }^{100}$ which some contend is adequate to protect the author's riglits. ${ }^{101}$ Since the marginal conpanies keep no accounts, the prosecuting composer must make a reasonable estimate of the number of unauthorized recordings; the number can rarely be shown to exceed 5,000, which gives a recovery of 400 dollars. While this recovery may approximate the immediate loss of a given composer or

96 Burton, Business Practices in the Copyright Field, 7 Copyrager Problems AnaryzedAn Analysis of tere Law of Copyright and Recent Developments 87, 112 (1957).

97 Copyrigert Law Revision, Part 2, at 267 (statement by Orme E. Cheatum).

98 Pasarow, 11 Buld. CR. Soc. 29 (1963). See also Subcomar. on Patents, Trademarks, \& Copyright, Comar. on the Judiclary, 86ri Cong., 2d Sess., Study No. 26: The UNAUTHORIzed DUPLICATION of Sound Recoroings (Comm. print 1961) (study by Barbara A. Ringer), concerned with the rights against the unauthorized dubbing of sound records.

99 Normal damage provisions for any other infringement are set out in 17 U.S.C. $\S 101(\mathrm{~b})$ (1964), but all infringements involving use of mechanical reproduction of music are under $\$ 101(e)$.

100 But cf. NAMarer, CopYrigirt 494-96 (1964), who presents the argument that damages can be multiplied up to 26 cents per record. Assume the unauthorized user fails to pay the statutory 2 cents per record under $\S 101(\mathrm{e})$, this makes the infringer liable (referring back to $\S 1(e)$ ) for 2 cents plus three times 2 cents or 8 cents per record even if the owner has made no demand for late payment. Under $\S 101(\mathrm{e})$ there is a further provision which allows three times the amount computed under $\S 1$ (e) for failure to give notice of use to the copyright owner. Since 8 cents per record las already been computed under $\$ 1$ (e), three times this anrount equals 24 cents per record. The final 2 cents per record comes from the basic royalty fee. This interpretation is doubtful since if the defendant is an infringer under $\S 101(\mathrm{e})$ for failing to file notice of intent to use, lie probably cannot he considered a licensee who is in default on the basic 2 cents per record as well.

101 STUDY No. 5, at 71 (comment by Sydney M. Kaye). 
publisher, it in no way serves to deter other companies from trying to avoid filing notice of use and paying royalties.

Record companies suggest that elimination of the statutory license system will not solve the problem of manufacturers who record without authorization, but that the answer lies in increased civil and criminal remedies. ${ }^{102}$ This suggestion was incorporated in the proposed act, which provides that failure to serve or file notice forecloses the possibility of a compulsory hicense, and in the absence of a negotiated license, the making and distribution of phonorecords are fully actionable as acts of infringement. ${ }^{103}$ Damages in an infringement action can be calculated on the basis of actual damages suffered, plus profits of the infringer that are attributable to the infringement and are not taken into account in computing the actual damages. ${ }^{104}$ Alternately, the copyright owner may elect an award of statutory damages which is not less than 250 dollars nor more than 10,000 dollars as the court considers just. ${ }^{105}$ Further, if the copyright owner can sustain the burden of showing the infringement was committed willfully after notice to desist, the court at its discretion may increase the award to a maximum of 20,000 dollars; if the infringer shows that lie neither knew nor had reason to believe that his actions constituted an infringement, the damages may be reduced to not less than 100 dollars. ${ }^{106}$ The proposed act also includes provisions for costs and attorneys' fees for any infringement ${ }^{10 \tau}$ and the possibility of criminal action. ${ }^{108}$ Such strong sanctions seem more than adequate to deter record compames from fraudulently reproducing recorded music without notifying the copyright owner, while estabhishing a satisfactory recovery as damages for unauthorized use of the composition.

\section{Distorted Use}

A lesser fear of the composer than collection of royalties is his inability to control the recording of a distorted version of his composition which would lower the value of the work as a whole. The present copyright statute under compulsory license permits any other person to make "similar use" of his copyrighted work. ${ }^{100}$ The licensee is permitted wide latitude in preparing his own adaptation, probably to the extent

102 Copyright Law Reviston, Part 4, at 431 (RIAA Statement); Copyriget Law Revision, ParT 2, at 70 (statement by Clive J. Davis, Columbia Records).

103 Proposed Act \& 113(b) (2).

104 Proposed Act $\$ 504(\mathrm{~b})$.

105 Proposed Act $\$ 504$ (c) (1).

106 Proposed Act $\$ 504$ (c) (2).

107 Proposed Act $\$ 505$.

108 Proposed Act $\$ 506$.

10017 U.S.C. \& 1 (e) (1964). 
that any use which is a recording use, will be regarded as a similar use..$^{110}$ At a minimum, the hicensee has "some latitude"-even if he does not have complete freedom to alter or distort the character of the copyrighted work. ${ }^{111}$ In practice, the music publishers do not seem at all eager to restrict the freedom of the record manufacturer to adapt the work in whatever way he thinks best for the particular artists he is planning to use. ${ }^{112}$ Besides, popular musical compositions frequently reach the record companies in the form of "lead sleets" which contain nothing but the melodic hine in single notes, accompanied by the lyrics, if any. To convert the piece of music into a commercially acceptable recording, the phonograph record manufacturer must have a complete orchestral arrangement made at a substantial cost. ${ }^{113}$ Nevertheless, a religious song can be turned into a rock and roll piece, thereby undermining its value to the composer. The record manufacturers claim the copyright owner presently has a remedy by the means of an action for infringement or perhaps defamation if the adaptation tends to bring the composer into disrepute. ${ }^{114}$ If the statute is in need of clarification, record manufacturers suggest the recording be subject to the doctrine of "fair use"115 but in any case the problem is capable of solution by means other than scrapping the entire statutory license system.

The proposed act attempts to define more clearly the use which the licensee may make of the musical arrangement. A compulsory license would include the privilege of making a musical arrangement of the work to the extent necessary to conform it to the style or manner of interpretation of the performance involved, but the arrangement could not change the basic melody or fundamental character of the work, except with the express consent of the copyright owner. Also, the arrangement would not be subject to protection as a derivative work, except with the copyright owner's consent. ${ }^{116}$ The proposal would allow adaptation from the "lead sheet" or basic composition to meet the needs of the performing artist; but to change the work, for example, from re-

110 Granz v. Harris, 98 F. Supp. 906 (S.D.N.Y. 1951), modified, 198 F.2d 585 (2d Cir. 1952); NAmmer, Copyriger 429 (1964); Diamond, Copyright Problents of the Phonograph Record Industry, 8 BuLx. CR. Soc. 337, 344 (1961).

111 Edward B. Marks Music Corp. v. Foullon, 79 F. Supp. 664, 667 (S.D.N.Y. 1948), aff'd, 171 F.2d 905 (2d Cir. 1949).

112 Diamond, supra note 110, at 344-45.

113 Copyright LAW Reviston, PART 4, at 430-31 (RIAA statement).

114 Copyriget Law Revision, Part 4, at 430-31; Study No. 5, at 70 (comment by Sydney M. Kaye).

115 Copyriget Law Revision, Part 4, at 431 (RIAA statement).

116 Proposed Act $\$ 113$ (a) (2). 
ligious in nature to rock and roll, the copyright owner's express consent would be required.

\section{Scope of the Compulsory License}

Under existing law there is some question as to whether the compulsory license provisions apply to tape recordings, motion picture sound tracks, television recordings and the like. Although motion picture synchromization riglits would come within the term "meclianical reproduction of the inusical work," under trade practices movie producers pay large sums for the use of previously recorded music in their pictures. ${ }^{117}$ The copyright owner-or an agent such as the Harry Fox Office-and the motion picture producer usually negotiate a single payment which may run as high as 20,000 dollars, depending on the place the musical composition will have in the film, for the right to use the music on the sound track and for the performing rights. ${ }^{118}$ Can a recording company, however, demand a compulsory license to record music which first appears as part of a motion picture sound track? The better view, which the industry takes, is that the sound track is copyrighted as an integral part of the motion picture film, and is not amenable to compulsory license until the copyright owner authorizes manufacture in recorded form. ${ }^{119}$

The proposed act clarifies the scope of compulsory license by limiting the operation strictly to "phonorecords."120 The trade practice is incorporated so that no person may obtain a compulsory license to distribute records of the work until the copyright owner authorizes distribution of phonorecords. ${ }^{121}$ Further, "a person may obtain a compulsory license only if his primary purpose in making phonorecords is to distribute them to the public for private use."122 The proposal would allow the copyright owner to collect royalties under compulsory license on extended tapes or any other form of reproduction which is sold to the public for private use. The copyright owner would retain the right, however, to license the use of his composition in motion pictures, and probably in television, and to negotiate the fee for such use. At the same

117 Lorimer, 2\$ Plain, Why Pay More, 10 U.C.L.A.L. Rev. 561 (1963). Lorimer argues that Congress intended any recorded use to subject the work to compulsory license for any other type of recorded use under section $1(\mathrm{e})$. Thus movie producers should refuse to pay any more than two cents royalty. NAMMER, CopyrJert 439 (1964).

118 STUDY No. 6, at 96-97.

119 NTMMMER, COPYRIGHT 111 (1964); STUDY No. 6, at 97.

120 "Phonorecords" are defined as "material objects in which sounds, other than those accompanying a motion picture, are fixed by any method now known or later developed, and from which the sounds can be perceived, reproduced, or otherwise communicated, either directly or with the aid of machine or device." Proposed Act § 101.

121 Proposed Act \& 113(a)(1).

122 Ibid. 
time, by allowing use of the music in a motion picture, the composer would not open up his composition to compulsory license as to phonograph records if he had not yet authorized such recordings.

\section{CONCLUSION}

Continuation of compulsory hicense in United States copyright law assures continued stability $m$ the music industry. Many of the practices and policies of the recording industry are based on customs which have developed from contracts between record manufacturers and composerpubhisher representatives. If the copyright statute has not been followed in negotiating private agreements, it has at least set guidehines and limitations for the contracting parties. The balancing of the arguments for and against elmination of compulsory hicense shows that a drastic change from the status quo may not be warranted when there is a solution, short of complete ehmination of compulsory hicense, which has the support of inost of the record industry. ${ }^{123}$

Since the proposed retention of compulsory license with modifications has received support from composer-publishers, the modifications must deal with nnajor complaints of the publisher groups. The arguments by composer-publishers for freedom to contract and for control over quality of recordings should be recoguized as spurious or at least of only minor significance; the real interest of the song owners is to insure adequate compensation for the mechanical reproduction of their music. As long as the principle of compulsory license is retained, allowing guaranteed access to copyrighted music for recording purposes, the record manufacturers will agree to increased royalties and stiffer penalties for nonpayment of royalties or distorted use of the composition..$^{124}$

The compromise whicli has resulted by continuing the compulsory hicense system but modifying royalties, damages, and other provisions is perhaps the best result. The alternative-eliminating compulsory hicense-besides creating disorder in the record industry, might deprive the public of the variety of renditions of such compositions as well as increasing the cost of phonorecords. On the other hand, the present compulsory license statute fails to guarantee the composer or publisher the protection or compensation he deserves for his music. The modified compulsory license proposal has reached a correct and workable result between the two extremes; it should be accepted and passed as part of the revised copyright law.

William $F$. Whiting*

123 Kaminstein, The McClellan-Celler Bill for General Revision of the United States Copyright Law, 10 N.Y.L.F. 147, 149 (1964).

124 Copyright Law Revision, ParT 4, at 431 (RIAA statement).

* LL.B. 1965, University of California, Berkeley. 